\title{
Female executive dan manajemen laba: Riset pada perusahaan manufaktur di Indonesia
}

\author{
Anindya Setya Suciani, Hari Purnama \\ Universitas PGRI Yogyakarta, Indonesia \\ sucianindyasetya@gmail.com
}

\begin{abstract}
Abstact: This study aims to test the effect of female executives on earnings management. The research was conducted at the manufacturing company listed on the Indonesia Stock Exchange in the 2015-2017 period. The purposive sampling was used 75 companies as data sample. Multiple linear regression test is used to see the effect of the independent variable on the dependent variable. The result of the analysis shows that the Female Chief Executive Officer (CEO), Female Chief Financial Officer (CFO) and Female Board of Commissioner does not influence earnings management. Whereas, the growth variable affects earnings management.
\end{abstract}

Keyword: Female executive; loss; growth; earnings management.

\section{Pendahuluan}

Perusahaan yang baik memiliki tata kelola dan struktur organisasi dewan yang memiliki pengaruh kuat terhadap manajemen puncak, dimana pengaruh yang timbul dapat mempengaruhi kinerja suatu perusahaan (Kim et al, 2009). Tidak hanya itu, saat dimulai era globalisasi para investor menuntut kinerja anggota dewan yaitu komisaris dan direksi sesuai harapan kepada perusahaan. Salah satu cara untuk memenuhi keinginan investor dengan diterapkannya keberagaman gender dalam perusahaan. Keberagaman ini diharapkan dapat mendorong komisaris dan direksi untuk mengelola perusahaan sehingga dapat berkembang di masa yang akan datang (Ramadhani dan Desi, 2017).

Earnings management merupakan suatu pengungkapan harapan manajerial atas informasi arus kas perusahaan. Artinya, upaya oportunis seseorang dalam kebebasan memilih, menggunakan, dan merubah metode serta prosedur akuntansi yang ada (Sulistyanto, 2008). Suatu badan usaha dapat melakukan tindakan oportunis berupa earnings management untuk mencapai suatu tujuan tertentu (Scott, 2009). Tujuan yang ingin dicapai oleh suatu perusahaan tertuang dalam laporan keuangan yang dibuat oleh perusahan. Informasi laporan keuangan digunakan oleh dua pihak yang berkepentingan yaitu pihak dalam dan luar perusahan. Pihak luar seperti investor, kreditur, pemerintah, dan umum. Hal ini yang membuat manajer melakukan earnings management karena semakin tinggi kualitas pelaporan laba, maka akan semakin meningkatkan ekspetasi penilaian investor pada perusahaan.

Pada struktur organisasi dalam perusahaan terdapat beberapa pihak yang terlibat dalam pelaporan keuangan yaitu Chief Executive Officer (CEO), Chief Financial Officer (CFO), dewan komisaris dan komite audit. Para pihak tersebut ada yang berhubungan langsung maupun tidak langsung dengan laporan keuangan. Pihak yang terlibat secara langsung terhadap pelaporan keuangan, seperti Chief Executive Officer (CEO) dan Chief Financial Officer (CFO) karena kedua pihak ini memiliki peran penting dalam menandatangani dan bertanggungjawab atas 
kandungan informasi pada pelaporan keuangan. Sedangkan, pihak yang tidak terlibat secara langsung, seperti pihak dewan komisaris dan komite audit karena peran kedua pihak hanya mengawasi dan meninjau kembali informasi laporan keuangan yang disajikan oleh perusahaan (Maula dan Arif, 2018).

Pada penelitian ini, peneliti akan memperluas cakupan variabel dari penelitian (Sugiarto dan Rudiawarni, 2017) dimana variabel yang digunakan adalah variabel Female CEO dan Female CFO. Sedangkan penelitian ini menambahkan variabel Female Board of Commisioners, Loss, dan Growth. Menurut Peni dan Vahaam (2010) wanita dan pria memiliki tindakan yang berbeda dalam gaya memimpin suatu perusahaan, gaya komunikasi, konservatisme, mengindari suatu risiko dan pada saat pengambilan keputusan. Pada penelitian terdahulu menyatakan bahwa keberadaan CEO wanita maupun Female CFO akan menurunkan tingkat manajemen laba perusahaan (Gavious et al, 2012). Sedangkan keberadaan wanita tidak berkaitan dengan manajemen laba pada perusahaan (Soebyakto et al, 2018). Selain itu, hampir semua perusahaan melakukan manajemen laba untuk menghindari kerugian yang terjadi pada perusahaan (Subekti, 2012); dan pertumbuhan pendapatan yang terjadi pada perusahaan akan mempengaruhi manajemen laba perusahaan (Suastini et al, 2016).

\section{Pengembangan hipotesis}

Earning management merupakan suatu aktivitas manajerial yang dilakukan dengan memodofikasi laporan keuangan dengan cara mengganti informasi laporan keuangan atau mengganti metode akuntansi yang bertujuan untuk mendapatkan keuntungan bagi perusahaan itu sendiri (Sulistyanto, 2008). Bagi para praktisi earning management merupakan sebuah kecurangan. Dimana earning management mempengaruhi besar kecilnya laba yang diinformasikan oleh perusahaan. Sedangkan, bagi para akademisi earning management bukanlah sebuah kecurangan melainkan dampak aturan prinsip akuntansi. Namun bagi suatu badan usaha melakukan earning management ini untuk mencapai tujuan tertentu (Scott, 2009). Dengan melakukan earning management ini, laporan keuangan suatu badan usaha akan lebih berkualitas bagi pihak eksternal.

Meninjau dari litelatur psikologi dan penelitian manajemen bahwa terdapat perbedaan antara pria dan wanita dalam gaya memimpin suatu perusahaan. Perbedaan dapat dilihat dari cara berkomunikasi, sikap kehati-hatian, dan pengambilan keputusan pada suatu tindakan (Peni dan Vahamaa, 2010). Keberagaman gender dalam manajemen puncak perusahaan dapat mendorong keunggulan bersaing dibandingkan dengan perusahaan yang tidak memiliki keberagaman jenis kelamin (Erhardt et al, 2003). Keberagaman gender dalam manajemen puncak berpengaruh terhadap pelaporan keuangan suatu perusahaan (Krishnan dan Parsons, 2008). Menurut Emadi dan Mansour (2015) bahwa adanya direktur wanita akan berpengaruh terhadap manajemen laba perusahaan. Sedangkan menurut penelitian dari Ye et al (2010) menyatakan, dimana tidak ada perbedaan yang signifikan apabila manajemen puncak dipimpin oleh wanita maupun laki-laki. Dengan pernyataan terdahulu memperlihatkan bahwa seorang wanita tidak dipandang sebelah mata untuk mengelola suatu perusahaan. 
Chief Executive Officer (CEO) merupakan jabatan tertingi pada suatu perusahaan yang dapat dipercaya untuk mengambil keputusan pada perusahaan guna mencapai tujuan perusahaan, yaitu mendapatkan keuntungan (Wirawan dan Novialy, 2012). Apabila posisi CEO ini diisi oleh seorang wanita, maka pekerjaan yang dilakukan akan cenderung lebih berhati-hati dalam pengambilan keputusan, wanita akan memilih untuk menghindari risiko yang ada, dan wanita dapat berpengaruh terhadap earnings management perusahaan.Wanita cenderung untuk menganalisis sebuah masalah sebelum mengambil keputusan dan mengolah masalah menjadi sebuah penyelesaian alternatif dengan libih berhati-hati (Robbins dan Judge, 2008).

Saat ini kedudukan wanita dalam jajaran manajemen puncak menandakan bahwa tidak ada lagi perbedaan gender dalam mengelola perusahaan (Suherman, 2017). Wanita tidak dapat dipandang sebelah mata oleh pria karena kemampuan dalam mengelola sebuah perusahaan tidak diragukan lagi oleh pihak perusahaan. Pada penelitian terdahulu menunjukkan bahwa keberadaan Female CEO berpengaruh negatif terhadap earnings management (Gavious et al, 2012; Peni dan Vahamaa, 2010). Berdasarkan hasil penelitian tersebut, maka hipotesis penilitian sebagai berikut:

$H_{1}$ : Female Chief Executive Officer berpengaruh terhadap earnings management.

Chief Financial Officer (CFO) merupakan posisi yang bertanggungjawab dalam mengelola risiko pada bidang keuangan, dimana CFO juga bertanggungjawab atas pencatatan dan pelaporan laporan keuangan yang ada pada perusahaan. Earnings management sangat dipengaruhi oleh $\mathrm{CFO}$, karena proses keuangan perusahaan hingga produksi dan perhitungan angka-angka yang mengatur seluruh prosesnya adalah CFO (Jiang et al, 2008). CFO tidak hanya dapat diduduki oleh seorang pria melainkan dapat diduduki oleh seorang wanita. Perbedaan ini terjadi karena wanita dapat memiliki sikap konservatisme yang cukup tinggi, cenderung akan menghindari risiko dan lebih berhati-hati dalam bertindak dibandingkan dengan pria (Kusumastuti et al, 2006).

Kesempatan bisnis prespektif bisnis merupakan sebuah kesempatan yang diberikan kepada wanita untuk fokus pada sebuah fakta yang menyatakan bahwa keberadaan wanita dalam dewan direksi perusahaan merupakan sebuah suboptimal bagi perusahaan (Brammer et al, 2007). Dimana wanita harus menunjukkan eksistensi dalam kegiatan bisnis dan menduduki tempat manajemen puncak untuk memimpin. Penelitian terdahulu menunjukkan bahwa Female CFO berpengaruh negatif terhadap earnings management (Barua et al, 2010; Peni dan Vahamaa, 2010). Berdasarkan hasil penelitian tersebut, maka hipotesis penilitian sebagai beikut: $\mathrm{H}_{2}$ : Female Chief Financial Officer (CFO) berpengaruh terhadap earnings management.

Board of Commisioners merupakan sekelompok anggota dewan yang ditunjuk oleh pemegang saham yang bertugas untuk mengawasi proses kegiatan usaha suatu perusahaan dan memberikan nasehat kepada direktur perusahaan. Tugas dari board of commissioners untuk mengawasi kegiatan perusahaan akan mengarahkan tindakan dan kebijakan CEO dan CFO perusahaan untuk kualitas laba yang tercantum dalam laporan keuangan. Menurut Peni dan 
Vahamaa (2010) bahwa jenis kelamin pada eksekutif memiliki pengaruh terhadap earnings management dan terhadap laporan keuangan perusahaan. Oleh karena itu, sifat wanita yang konservatif, berhati-hati dalam mengambil keputusan dan memiliki sifat etika yang lebih baik ini akan berpengaruh terhadap earnings management perusahaan.

Keberadaan wanita dalam jajaran komisaris tidak berkaitan dengan praktek manajemen laba pada perusahaan (Soebyakto et al, 2018). Pada penelitian Krishnan dan Parsons (2008); Emadi dan Mansour (2015) menunjukkan dengan adanya keberadaan wanita pada posisi manajemen puncak dan dengan jumlah yang lebih banyak akan berdampak pada earnings management perusahaan, maka hipotesis penilitian sebagai beikut:

$\mathrm{H}_{3}$ : Female Board of Commisioners berpengaruh terhadap earnings management.

Kerugian (loss) merupakan suatu hasil yang tidak bermanfaat yang timbul dari kegiatan usaha (Itasari dan Kristanto, 2019). Setiap perusahaan yang melakukan kegiatan usaha akan menghindari kerugian yang dapat timbul akibat kegiatan usaha. Apabila perusahaan mengalami kerugian, maka akan menimbulkan dampak negatif terhadap pendapat para investor. Penelitian Roychowdhury (2006) dan Subekti (2012) mengatakan bahwa sebagian besar perusahaan untuk menghindari kerugian akan melakukan manajemen laba. Manajemen laba dilakukan untuk memperkecil kerugian yang terjadi pada kegiatan usaha. Berdasarkan hasil penelitian tersebut, maka hipotesis penelitian sebagai beikut:

$H_{4}$ : Loss berpengaruh terhadap earnings management.

Pertumbuhan perusahaan merupakan tolak ukur yang mencerminkan kemampuan perusahaan dalam mempertahankan pertumbuhan ekonomi pada kegiatan usaha perusahaan (Suastini et al, 2016). Pertumbuhan suatu perusahaan dapat dilihat melalui tingkat penjualan dari tahun ke tahun untuk mendapatkan pendapatan yang tinggi ataupun rendah. Semakin meningkat pertumbuhan suatu perusahaan, maka stakeholder akan semakin tertarik untuk berinvestasi pada entitas (Fauzan dan Purwanto, 2017). Pada penelitian Handayani dan Rachadi (2009) mengatakan bahwa terdapat pengaruh yang signifikan antara pertumbuhan penjualan dengan manajemen laba. Dimana penjualan yang tinggi akan diikuti oleh peningkatan pendapatan. Berdasarkan penelitian tersebut, hipotesis penelitian sebagai berikut:

$H_{5}$ : Growth berpengaruh terhadap earnings management.

\section{Metode penelitian}

Sampel yang digunakan pada penelitian ini menggunakan perusahaan go public yang tercatat pada Bursa Efek Indonesia tahun 2015-2017. Metode pengambilan sampel yang digunakan peneliti berupa purposive sampling dan sampel dipilih dengan kriteria tertentu (Budiarto, 2019), yaitu: (1) Perusahaan manufaktur yang terdaftar di Bursa Efek Indonesia; (2) Perusahaan manufktur yang memiliki female executive pada manajemen puncak perusahaan; (3) Perusahaan manufaktur yang menerbitkan laporan keuangan selama 3 tahun berturut-turut; (4) Perusahaan manufaktur yang memiliki kelengkapan data laporan keuangan selama tahun 2015-2017. 
Berdasarkan kriteria yang ada diperoleh sampel sebanyak 75 sampel dari beberapa perusahaan sebagaimana yang dijabarkan pada tabel di bawah ini:

Tabel 1. Sampel Penelitian

\begin{tabular}{llcccc}
\hline \multicolumn{1}{c}{ Kriteria yang digunakan } & 2015 & 2016 & 2017 & Total \\
\hline 1. & $\begin{array}{l}\text { Perusahaan manufaktur yang terdaftar di Bursa Efek } \\
\text { Indonesia }\end{array}$ & 146 & 150 & 150 & 446 \\
2. $\begin{array}{l}\text { Perusahaan manufktur yang tidak memiliki female } \\
\text { executive pada manajemen puncak perusahaan }\end{array}$ & 112 & 112 & 112 & $(336)$ \\
3. $\begin{array}{l}\text { Perusahaan manufaktur yang tidak menerbitkan laporan } \\
\text { keuangan selama 3 tahun berturut-turut }\end{array}$ & 2 & 6 & 6 & $(14)$ \\
4. Perusahaan manufaktur yang tidak memiliki kelengkapan \\
data laporan keuangan selama tahun 2015-2017
\end{tabular}

Sumber: data diolah tahun 2018

Data yang digunakan oleh peniliti berupa data sekunder. Dimana data sekunder merupakan data penelitian yang diperoleh melalui media perantara secara langsung maupun tidak langsung. Media perantara tidak langsung yang dimaksud berupa buku, catatan, bukti yang telah ada, atau arsip baik yang publikasi maupun yang tidak publikasi secara umum.

Variabel dependen pada penelitian ini adalah earnings management. Earning management yang dimaksud adalah yang berkaitan dengan discretionary accrual. Perhitungan discretionary accrual menggunakan Modified Jones Dechow (1994):

$$
\mathrm{NDACC}=\frac{1}{T A_{t-1}}+\alpha_{1}\left(\frac{\Delta R E V-\Delta R E C}{T A_{t-1}}\right)+\alpha_{2} \frac{P P E}{T A_{t-1}}+\varepsilon
$$

Keterangan:

$\mathrm{DA}=\frac{A C C-N D A C}{T A_{t-1}}$

$\mathrm{ACC}=$ Total Accrual (Net income - Operating Cash Flow)

TA = Total aset badan usaha pada tahun $\mathrm{t}-1 \mathrm{ke} \mathrm{t}$

$\triangle R E V=$ perubahan pendapatan badan usaha pada tahun $\mathrm{t}-1 \mathrm{ke} \mathrm{t}$

$\triangle R E C=$ perubahan pada piutang bdan usaha pada tahun $\mathrm{t}-1 \mathrm{ke} \mathrm{t}$

$\mathrm{PPE}=$ nilai kotor dari property, plant, and equipment pada akhir tahun $\mathrm{t}$

$\varepsilon \quad=$ unstandardized error

Variabel independen ini diukur menggunakan variabel dummy sama seperti penelitian (Sugiharto dan Rudiawarni, 2017). Variabel dummy mengambil nilai 0 (nol) untuk menunjukkan ketidak hadiran variabel yang dimaksud peneliti dan 1 (satu) untuk kehadiran variabel yang dimaksud peneliti. Perhitungan ini dilakukan pada variabel independen Female Chief Executive Officer (CEO), Female Chief Financial Officer (CFO), Female Board of Commisioner, loss dan growth.

Data yang telah diperoleh dari laporan keuangan dan annual report perusahaan. Teknik analisis data pada penilitian ini menggunakan metode regresi linear berganda untuk menganalisis pengaruh variabel bebas dengan variabel terikat. Regresi linear berganda pada penilitian ini dihitung dengan formula sebagai berikut: 


$$
\begin{aligned}
\mathrm{DAj}, \mathrm{t}= & \alpha_{0}+\beta_{1} \text { FEMALEj,t+}+\beta_{2} L E V j, t+\beta_{3} L O S S j, t+\beta_{4} M B j, t+ \\
& \beta_{5} R E V G R O W T H j, t+\beta_{6} S I Z E j, t+\sum_{k-1}^{n-1} \propto_{k} S I C K_{j}^{k}+\sum_{2015}^{2017} \omega_{y} Y E A R_{j}^{y}+ \\
& \varepsilon_{j, t}
\end{aligned}
$$

\begin{tabular}{|c|c|}
\hline DA & $=$ Discreationary Accruals \\
\hline FEMALE & $\begin{aligned}= & \text { Female Executive, } 1 \text { (satu) apabila CEO dan/atau CFO dan/atau Dewan } \\
& \text { Komisaris adalah wanita dan } 0 \text { (nol) jika tidak. }\end{aligned}$ \\
\hline LEV & $=$ Leverage Ratio \\
\hline LOSS & $\begin{aligned}= & \text { Negative Net Income, } 1 \text { (satu) apabila laba bersih periode berjalan adalah } \\
& \text { negatif dan } 0 \text { (nol) jika laba bersih periode berjalan adalah positif }\end{aligned}$ \\
\hline MB & $=$ Market to Book Ratio \\
\hline REVGROWTH & $=$ Revenue Growth \\
\hline SIZE & $=$ Ukuran perusahaan \\
\hline$\alpha$ & $=$ Konstanta \\
\hline$\beta$ & $=$ Koefisien regresi untuk pengujian hipotesis \\
\hline SIC & $=$ Dummy variabel berdasarkan kode klasifikasi standart industri \\
\hline YEAR & = Dummy variabel yang mengindikasi tahun fiskal perusahaan \\
\hline & $=$ error \\
\hline
\end{tabular}

Keterangan:

\section{Hasil penelitian dan pembahasan}

Deskripsi secara umum atas data-data penelitian pada masing-masing variabel yang digunakan dapat dilihat dalam tabel 2 berikut:

Tabel 2. Deskripsi Variabel

\begin{tabular}{cccccc}
\hline Variabel Penelitian & N & Minimum & Maximum & Mean & Std. Deviation \\
\hline DA & 72 & -0.54 & 0.95 & -0.0007 & 0.217 \\
FCEO & 75 & 0.00 & 1.00 & 0.2400 & 0.429 \\
FCFO & 75 & 0.00 & 1.00 & 0.2667 & 0.445 \\
FBC & 75 & 0.00 & 1.00 & 0.6800 & 0.469 \\
LOSS & 75 & 0.00 & 1.00 & 0.1600 & 0.369 \\
GROWTH & 75 & -29.51 & 48.34 & 5.962 & 14.385 \\
\hline
\end{tabular}

Sumber: data diolah tahun 2018

Berdasarkan hasil pengelolaan pada tabel 2 dapat dilihat dimana nilai rata-rata dari Discreationary Accruals (DA) sebesar -0.0007 dengan standar deviasi sebesar 0.217. Hasil ini menunjukkan bahwa rentan nilai Discreationary Accruals (DA) pada suatu perusahaan yang dipilih menjadi sampel penelitin ini tidak begitu luas. Sedangkan, hasil nilai Discreationary Accruals (DA) terkecil dalam penelitian ini diperoleh nilai sebesar -0.54 dan untuk nilai Discreationary Accruals (DA) terbesar diperoleh nilai sebesar 0.95.

Statistik deskriptif variabel independen yang dihasilkan pada tabel 2 yaitu, variabel FCEO mendapat nilai rata-rata sebesar 0.240, FCFO sebesar 0.267, dan FBC sebesar 0.680. Hasil ini menunjukkan bahwa dari total 75 sampel perusahaan manufaktur selama tahun 20152017, presentase perusahaan dengan wanita sebagai manajemen puncak adalah $24.0 \%$ untuk 
CEO wanita, 26.7\% untuk CFO wanita, dan $68.0 \%$ untuk Board of Commisioner wanita. Hasil ini menunjukan bahwa wanita memiliki peran yang cukup banyak dalam menduduki manajemen puncak suatu perusahaan.

Variabel LOSS pada penelitian ini memiliki nilai rata-rata sebesar 0.160 yang berarti 16\% sampel perusahaan mengalami kerugian. Sedangkan hasil dari variabel GROWTH menunjukkan nilai rata-rata sebesar 5.962. Hal ini menunjukkan bahwa sampel perusahaan yang digunakan memiliki rata-rata pertumbuhan sebesar 59.62\% dari tahun sebelumnya.

Tabel 3. Hasil Pengujian Regresi

\begin{tabular}{cccc}
\hline Variabel Penelitian & Koefisien Regresi & $\mathrm{t}$ & Sig. \\
\hline Constant & & 1.388 & 0.170 \\
FCEO & 0.087 & 0.721 & 0.473 \\
FCFO & 0.133 & 1.109 & 0.271 \\
FBC & -0.060 & -0.513 & 0.610 \\
LOSS & -0.164 & -1.402 & 0.165 \\
GROWTH & -0.305 & -2.562 & $0.013^{*}$ \\
\hline F $=2.892$ & & $0.042^{*}$ \\
Adj R ${ }^{2}=0.074$ & &
\end{tabular}

Pada tabel 3 menunjukkan bahwa Female CEO tidak berpengaruh terhadap manajemen laba. Hasil ini mendukung penelitian Peni dan Vahamaa (2010); Gavious et al (2012). Hasil Female $C E O$ yang tidak berpengaruh dapat terjadi, mengingat jumlah Female $C E O$ pada perusahaan manufaktur lebih sedikit dibandingkan dengan jumlah CEO laki-laki yang menjabat pada manajemen puncak (Novilia dan Nugroho, 2016). Melihat dari jumlah perusahaan manufaktur yang terdaftar di BEI selama tahun 2015-2017 sebesar 446 perusahaan, sedangkan perusahaan yang memiliki female executive sebesar 25 perusahaan.

Variabel Female CFO tidak berpengaruh terhadap manajemen laba. Hasil ini mendukung penelitian Peni dan Vahamaa (2010); Barua et al (2012). Kecenderungan seorang wanita dalam penilaian dan tingkat kecemasan yang lebih tinggi dibandingkan dengan laki-laki, mengakibatkan seorang wanita akan lebih menyalahkan diri sendiri apabila terjadi suatu kegagalan. Sedangkan, laki-laki memiliki rasa percaya diri yang dapat menyembunyikan suatu kegagalan yang terjadi (Gavious et al, 2012).

Variabel Female Board of Commisioner tidak berpengaruh terhadap manajemen laba. Hasil ini sesuai dengan penelitian Soebyakto et al (2018) dan bertolak belakang dengan penelitian Krishnan dan Parsons (2008); Emadi dan Mansour (2015) yang membuktikan sebaliknya. Terdapat tingkat kepedulian yang berbeda antara wanita dengan laki-laki, dimana wanita memiliki rasa kepedulian yang lebih besar dalam menjalin hubungan interpersonal dan berperilaku adil agar dapat menekan tindakan earnings management dalam perusahaan (Lakhal et al, 2015).

Variabel LOSS menunjukkan hasil tidak berpengaruh terhadap earnings management. Hasil ini berbanding terbalik dengan penelitian (Roychowdhury, 2006; Subekti, 2012). Pada dasarnya perusahaan akan menghindari kerugian, karena kerugian yang terjadi akan 
mempengaruhi keputusan para investor dalam menanamkan saham. Bagi perusahaan kerugian merupakan suatu hasil dari kegiatan usaha yang tidak bermanfaat (Itasari dan Kristanto, 2019).

Variabel GROWTH berpengaruh terhadap earnings management perusahaan. Hasil ini sesuai dengan penelitian Handayani dan Rachadi (2009) dimana perusahaan akan berusaha untuk meningkatkan pertumbuhan pendapatan setiap tahun agar memperoleh laba. Dimana laba yang diperoleh perusahaan akan mempengaruhi earnings management yang dilakukan perusahaan, karena semakin tinggi tingkat pendapatan yang diperoleh perusahaan, maka akan semakin baik respon stakeholder terhadap perusahaan (Fauzan dan Purwanto, 2017).

\section{Kesimpulan keterbatasan dan saran}

Penelitian ini menguji pengaruh Female CEO, Female CFO, Female Board of Commisioners, Loss, dan Growth terhadap manajemen laba pada perusahaan manufaktur yang terdaftar di Bursa Efek Indonesia pada tahun 2015-2017. Berdasarkan hasil penelitian dapat ditarik kesimpulan bahwa perusahaan dengan Female CEO, Female CFO, Female Board of Commisioner dan variabel Loss tidak memiliki pengaruh terhadap manajemen laba. Sedangkan, variabel Growth memiliki berpengaruh terhadap manajemen laba perusahaan manufaktur.

Pada penelitian ini memiliki beberapa keterbatasan seperti, pengukuran manajemen laba hanya berdasarkan manajemen laba akrual yang diukur dengan Discretionary Accruals (DA). Selain menggunakan pengukuran akrual, manajemen laba dapat diukur dengan manajemen laba riil. Kedua, inteprestasi dilakukan tanpa mempertimbangkan jenis industri pada perusahaan manufaktur sehingga dapat menjadikan bias karena aktivitas manajemen laba pada setiap industri berbeda-beda. Penelitian selanjutnya dapat menambah karakteristik pada manajemen puncak seperti, latar belakang pendidikan dan pengalaman dalam bidang yang bersangkutan (Novilia dan Nugroho, 2016).

\section{DAFTAR PUSTAKA}

Barua, A., Davidson, L.V.,Rama, D.V., \& Thiruvadi, S. (2010). CFO Gender and accruals quality. Accounting Horizons, 24: 25-39.

Brammer, S., Millington, A., dan Rayton, B. (2007). The contribution of corporate social responsibility to organizational commitment. International Journal of Human Resource Management, 18(10), 1701-1719.

Budiarto, D.S. (2019). Panduan Riset Kuantitatif: Trik Publikasi bagi Pemula. Edisi 1, Penerbit UPY-Press. Yogyakarta

Dechow, P. M, Sloan., R.G., \& Sweeney, A.P. (1995). Detecting eanings management. The Accounting Review, 70(2), 193-225

Emadi, G. \& Mansour, G. (2015). The association presence of female members on the board of directors and earnings management with discretionary accruals indexion the listed companies in Tehran Stock Exchange. Journal of Current Research in Science, 3(1), 3943.

Erhardt, N., Werbel, J. and Shrader, C. (2003). Board of director diversity and firm financial performance. Corporate Governance: An International Review, 11, 102-10. 
Fauzan, M., \& Purwanto, A. (2017). Pengaruh pengungkapan CSR, timeliness, profitabilitas, pertumbuhan perusahaan dan resiko sistematik terhadap earnings response coefficient (ERC). Journal of Accounting, 6(1), 1-15.

Gavious, I. A., Einav, \& Rami, Y. (2012). Female directors and earning management in hightechnology firms Israil. Guilford Glazer Faculity of Business And Management at Bengurion University

Gu, Z., C.W.J. Lee \& Rosset, J.G. (2005). What determines the variability of accounting accruals? Review of Quantitative Finance and Accounting, (24), 313 - 314.

Handayani, R. S., \& Rachadi, A. D. (2009). pengaruh ukuran perusahaan terhadap manajemen laba. Jurnal Bisnis dan Akuntansi. 11(1), 33-56

Itasari, R. N., \& Kristanto, A. B. (2019). Kerugian konvergensi IFRS di Indonesia. MODUS, 31(1), 1-21.

Jiang, J., Petroni, K., \& Wang, I. (2008). CFOs and CEOs: Who has the mostinfluence on earnings management, Working Paper. Michigan State University. East Lansing.

Kim, K., Nofsinger, J., \& Mohr, D. (2009). Corporate Governance. 3rd Edition. London: Prentice Hall.

Krishnan, G. P., \& Parsons, L.M. (2008). Getting to the bottom line: An exploration of gender and earnings quality. Journal of Business Ethics, 78, 65-76.

Kusumastuti, S., Supatmi., \& Perdana, S. (2006). Pengaruh board diversity terhadap nilai perusahaan dalam perspektif corporate governance. Jurnal Akuntansi dan Keuangan, 9(2), 88-98.

Lakhal, F., Aguir, A., Lakhal, N., \& Malek, A. (2015). Do women on boards and in top management reduce earnings management? Evidence in France. Journal of Applied Business Research, 31(3), 1107-1118.

Maula, K.A., \& Arif, R. (2018). Pengaruh board diversity (CEO wanita, CFO wanita, proporsi dewan komisaris wanita, dan proporsi komite audit wanita) terhadap pelanggaran aturan laporan keuangan. Accounthink: Journal of Accounting and Finance, 3(1), 431-445

Novilia, O., \& Nugroho, P.I. (2016). Pengaruh manajemen puncak wanita terhadap manajemen laba. Dinamika Akuntansi, Keuangan, dan Perbankan, 6(1), 27-47.

Peni, E., \& Vahamaa, S. (2010). Female executive and earnings management. Managerial Finance Journal. 36(7), 629-645.

Ramadhani, Z. I., \& Desi A. (2017). Semakin beragam semakin baik? Isu keberagaman gender, keuangan, dan investasi perusahaan. Jurnal Keuangan dan Perbankan, 21(1), 1-13

Robbins S. P., \& Judge. (2008). Perilaku Organisasi. Jakarta: Salemba Empat.

Roychowdhury, S. (2006). Earning management through real activities manipulation. Journal of Accounting and Economics, 42, 335-370.

Scott, W. R. (2009). Financial Accounting Theory. Fifth Edition. Canada Prentice Hall.

Sulistyanto, S. (2008). Manajemen Laba Teori dan Model Empiris. Jakarta: Grasindo.

Suastini, N. M., Purbawangsa, I.B.A., \& Rahyuda, H. (2016). Pengaruh kepemilikan dan pertumbuhan perusahaan terhadap nilai perusahaan pada perusahaan manufaktur di Bursa Efek Indonesia. Jurnal Ekonomi dan Bisnis, 5(1), 143-172.

Subekti, I. (2012). Accrual and real earning management: One of the perspective of prospect theory. Journal of Economics, Business, and Accountancy Ventura, 15(3), 443-456.

Soebyakto, B.B., Mukhtaruddin., Harun, D., Kencana, D., \& Pratama, A.F. (2018). Female commisioner and director, and earnings management: study on manufacturing 
companies listed on Indonesia Stock Exchange. Academy of Accounting and Financial Studies Journal. 22(4), 1-10.

Sugiharto, A.K.A., \& Rudiawarni, F.A. (2017). Pengaruh female executive terhadap laporan keuangan pada sektor manufaktur yang terdaftar di BEI periode 2012-2014. Jurnal Akuntansi dan Teknologi Informasi (JATI), 11, 1-19.

Suherman. (2017). Pengaruh CEO wanita terhadap cash holding perusahaan. MIX: Jurnal Ilmiah Manajemen, 7(1), 48-58.

Wirawan, G., \& Novialy, Y. (2012). Indikasi manajemen laba oleh chief executive officer (CEO) baru pada perusahaan yang terdaftar di Pasar Modal Indonesia. Jurnal Akuntansi dan Bisnis, 7(1), 1-24.

Ye, K., Z. Ran., \& Zabiollah, R. (2010). Does top executive gender diversity affect earnings quality? A large sample of Chinese Listed Firms. Advances in Accounting, incorporating Advances in International Accounting, 26, 47-54. 